\title{
Intestinal Parasitic Infections and Hemoglobin Levels among Schoolchildren participating in a Deworming Program in Jakarta, Indonesia: A Cross-sectional Study
}

\author{
Rizal Subahar*, Lisawati Susanto, Hendri Astuty, Rawina Winita, Ika Puspa Sari \\ Department of Parasitology, Faculty of Medicine, University of Indonesia, Depok, Indonesia
}

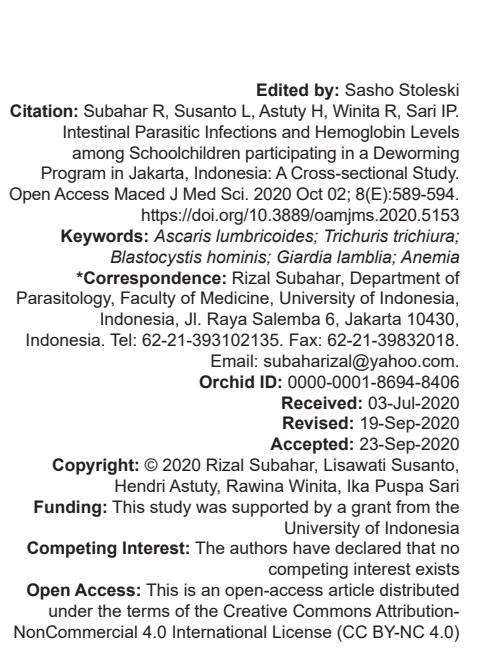

\section{Abstract}

BACKGROUND: Deworming programs have had positive impacts on the incidence of intestinal parasitic infections (IPIs) and hemoglobin ( $\mathrm{Hb}$ ) levels among schoolchildren.

AIM: This study aimed to evaluate effects of a deworming program on IPIs and $\mathrm{Hb}$ levels among schoolchildren in Jakarta, Indonesia

METHODS: A cross-sectional study was performed in one school in Jakarta, Indonesia. Stool samples from schoolchildren were examined using the direct smear and Kato-Katz methods. The Hb concentrations of the schoolchildren were measured using the Easy Touch $\mathrm{GCHb}$ tool kit.

RESULTS: A total of 219 stool samples were obtained, and $18.7 \%$ (41/219) were positive for IPIs; specifically $8.2 \%$ $(18 / 219)$ were positive for helminth and $10.5 \%$ (23/219) were positive for protozoan infections. The prevalences of Ascaris lumbricoides and Trichuris trichiura were $6.4 \%$ and $1.8 \%$, respectively. The prevalences of Blastocystis hominis, Giardia lamblia, Entamoeba histolytica, and Entamoeba coli were $6.8 \%, 2.7 \%, 0.5 \%$, and 0.5\%, respectively. The prevalence of anemia $(\mathrm{Hb}<11.5 \mathrm{~g} / \mathrm{dL})$ among the schoolchildren was $19.6 \%(43 / 219)$. The IPIs were significantly associated with $\mathrm{Hb}$ concentrations among the schoolchildren $(\mathrm{p}<0.05)$.

CONCLUSION: The results of this study support the use of integrated programs involving deworming, nutrient supplementation, development of good living conditions, use of sanitary facilities, and active participation in the community to reduce IPIs and to improve the nutritional status among schoolchildren.

\section{Introduction}

Intestinal parasitic infections (IPIs) are caused by pathogenic helminth and protozoan species. These parasites live in the human intestinal tract and induce intestinal alterations, resulting in serious mortality and morbidity in humans. IPIs are harmful diseases and are endemic worldwide. Estimates for those infected with Ascaris lumbricoides, Trichuris trichiura, and hookworm are 800-1221 million, 604-795 million, and 576-740 million, respectively [1]. There are approximately 50 million people living with Entamoeba histolytica infections, and Giardia lamblia has infected about 3 million people worldwide [2], [3].

In soil-transmitted helminth (STH) infections, heavy infection with $A$. lumbricoides causes lactose intolerance, Vitamin A malabsorption, intestinal obstruction, and hepatopancreatic ascariasis. T. trichiura causes colitis, trichuriasis syndrome, and rectal prolapse, while hookworm causes iron deficiency anemia and protein malnutrition [1], [4], [5]. G. lamblia causes diarrhea, malaise, flatulence, greasy stool, and abdominal cramping [6]. The symptoms of $B$. hominis infection are mostly non-specific and include acute and chronic diarrhea, nausea, vomiting, flatulence, abdominal pain, and anorexia [7]. Heavy infections with E. histolytica cause fever, abdominal tenderness, vomiting, and bloody diarrhea with 10-20 movements/day [8].

School-aged children represent the group that is the most frequently infected with IPIs compared to other populations [9]. For these reasons, the WHO has recommended the use of deworming programs in primary schools to control the morbidity caused by STH infections. The deworming programs are simple and should be administered to children even without a previous individual diagnosis [10]. In addition, the deworming program using albendazole (single dose, $400 \mathrm{mg}$ ) has been shown to decrease the prevalences of $A$. lumbricoides, T. trichiura, and hookworm [10], [11]. However, Quihui-Cota and Morales-Figueroa [12] reported that IPIs persisted despite a national deworming campaign in schoolchildren in Northwestern Mexico because albendazole alone was not sufficient to improve the health conditions of the vulnerable population.

Deworming programs, which provide a blanket treatment, are implemented in many countries, including 
Indonesia. Jakarta, the capital city of Indonesia, has implemented a deworming program since 1990. This study was conducted in a primary school in Kalibaru subdistrict, North Jakarta, Indonesia, for several reasons. First, because deworming programs have been shown to decrease the morbidity of STH infections [10], the effectiveness of the local program was assessed. Second, although the deworming program is implemented in primary schools, intestinal parasite infections may persistent in areas characterized by poor living conditions and low family income [1], [12]. Finally, IPIs in schoolchildren impact $\mathrm{Hb}$ concentrations [13]. Thus, this study aimed to evaluate the effects of the deworming program on IPIs and $\mathrm{Hb}$ levels among schoolchildren in Jakarta, Indonesia.

\section{Materials and Methods}

\section{Ethical approval}

This study obtained ethical approval from the Health Research Ethics Committee of Faculty Medicine (No. 521/UN2.F1/ETIK/VII/2016.), University of Indonesia, Jakarta, Indonesia.

\section{Study design and site}

This cross-sectional study was conducted in a primary school, SDN Kalibaru 09, located in Kalibaru Subdistrict, North Jakarta. Jakarta is located in Jakarta Province, and Jakarta is the capital city of Indonesia.

\section{Demographic data}

All of the participants, teachers, parents, and schoolchildren were provided with health education by the research team, which included a medical doctor. The health education consisted of the etiology of IPIs, their signs and clinical manifestations, diagnosis, treatment, and prevention of intestinal parasite infections. Furthermore, all of the parents were interviewed by a research team member using a standard questionnaire to obtain their demographic data, including education, occupation, household income, water sources, and the defecation facilities.

\section{Stool examination}

In this study, only stool samples collected from the schoolchildren were examined. Stool examinations were conducted using the Kato-Katz method to detect STH eggs and the direct smear method to detect intestinal protozoan cysts. For direct fecal smears, iodine wet mounts were prepared following the WHO procedures [14]. About $2 \mathrm{mg}$ of a stool sample was suspended in Lugol's staining solution and then observed microscopically. The Kato-Katz method was conducted following the WHO procedures as follows. Hydrophilic cellophane strips (40-50 $\mu \mathrm{m}$ thick strips, 25 $\times 30 \mathrm{~cm}$ in size) were cut and immersed in 3\% glycerolmalachite green solution for at least $24 \mathrm{~h}$ before use. A single thick smear slide was prepared using a $41.7 \mathrm{mg}$ punched plastic template. The total helminth egg count was recorded and then converted to eggs per gram of stool by multiplying the number of eggs per slide by 24 .

\section{Hb measurement}

Easy Touch $\mathrm{GCHb}$ test strips were used to measure $\mathrm{Hb}$ following the manufacturer's recommendations for the procedure and interpretation of the results [15]. Briefly, one strip was taken from the vial of hemoglobin $(\mathrm{Hb})$ test strips, and the vial was closed quickly. The test strip was inserted into the test strip slot on the meter. The meter first displayed the code number and then the blood symbol. The lancing device was placed on a finger, and the trigger on the device was pressed. After the lancing device was withdrawn, the first drop of blood was wiped away, and a second one was allowed to form. The drop of blood was placed in the test well of the meter, and a beep sounded when there was a sufficient amount of blood. The meter then counted down from 6 , showed the result on the screen, and automatically stored it in its memory. The $\mathrm{Hb}$ value was recorded on the provided log sheet.

\section{Statistical analysis}

SPSS ver. 20.0 was used to analyze all of the data. Chi-square tests were used to determine whether the prevalence rates of intestinal parasites differed between female or male students and whether intestinal parasites affected $\mathrm{Hb}$ levels among schoolchildren [16]. Body weight in kilograms $(\mathrm{kg})$ was measured for all of the schoolchildren using a bodyweight tool. Their height in centimeters $(\mathrm{cm})$ was measured with a body height tool. The body mass index (BMI) was calculated using the BMI formula: Body weight/(body height $x$ body height). Anemia among the schoolchildren was determined following the method described in a previous study [17]. Hb concentrations $<11.5 \mathrm{~g} / \mathrm{dL}$ for those $6-11$ years old and $12.0 \mathrm{~g} / \mathrm{dL}$ for those $12-15$ years old were determined as anemia. The study used $p<0.05$ to indicate statistical significance.

\section{Results}

\section{Demographic data of the respondents}

A total of 188 respondents (parents) participated in the study, and their data are shown in 
Table 1. The respondents' education levels included illiterate, primary school, junior high school, senior high school, and one with higher education, undergraduate. Most of the respondents did not have jobs, working only as homemakers. A total of $179(94.7 \%)$ respondents reported more than 1 US\$ per day for household income. They also had latrines in their houses and used various water sources, including wells, pumps, and piped water. Tap water was available in the primary school.

Table 1: Demographic data of the respondents from Kalibaru 09 PG Primary School in North Jakarta, Indonesia

\begin{tabular}{lll}
\hline & $\mathrm{n}$ & $\%$ \\
\hline Total respondents & 188 & \\
Education & & \\
$\quad$ Illiterate & 32 & 17.0 \\
$\quad$ Primary school & 83 & 44.1 \\
$\quad$ Junior high school & 39 & 20.7 \\
$\quad \begin{array}{l}\text { Senior high school } \\
\text { Undergraduate }\end{array}$ & 33 & 17.6 \\
Job & 1 & 0.6 \\
$\quad$ Not employed & 185 & 98.4 \\
$\quad$ Employed & 3 & 1.6 \\
Income & & \\
1 US\$ per day & 10 & 5.3 \\
1 US\$ per day & 178 & 94.7 \\
Latrine & & 2.7 \\
$\quad$ No latrine in house & 5 & 97.3 \\
$\quad$ Latrine in house & 183 & 91.2 \\
Water sources (in household) & & 1.6 \\
$\quad$ Piped & 179 & 3.2 \\
$\quad$ Well & 3 & 100.0 \\
$\quad$ Pump & 6 & \\
$\quad$ Tater sources (in the primary school) & & \\
\hline
\end{tabular}

\section{Prevalence of IPIs}

In this study, 219 stool samples were collected from schoolchildren in Jakarta. Identified intestinal parasites included $A$. lumbricoides eggs, T. trichiura eggs, G. lamblia cysts, E. histolytica cysts, Entamoeba coli cysts, and Blastocystis hominis cysts. Overall, 41 schoolchildren were infected with one or more intestinal parasite; 37 schoolchildren had a single intestinal parasite infection, and 4 schoolchildren had a double intestinal parasite infection (helminth and protozoan infections). The prevalence of intestinal parasites among the schoolchildren was $18.7 \%$ (41/219). The prevalences of $A$. lumbricoides and $T$. trichiura were $6.4 \%(14 / 219)$ and $1.8 \%(4 / 219)$, respectively. The prevalences of G. lamblia, E. histolytica, E. coli, and B. hominis were $2.8 \%(6 / 219), 0.5 \%(1 / 219), 0.5 \%$ (1/219), and 6.8\% (15/219), respectively (Table 2).

The intestinal parasites with the highest frequencies among the schoolchildren in Jakarta were $B$. hominis, A. lumbricoides, and G. lamblia; E. histolytica,

Table 2: Intestinal parasites among schoolchildren in Jakarta

\begin{tabular}{|c|c|c|c|c|c|c|c|}
\hline \multirow[t]{2}{*}{ Grade } & \multirow{2}{*}{$\begin{array}{l}\text { Number of } \\
\text { samples }\end{array}$} & \multicolumn{6}{|c|}{ Intestinal parasite } \\
\hline & & $\mathrm{Al}$ & Tt & $\mathrm{Gl}$ & Eh & Ec & $\mathrm{Bh}$ \\
\hline 4 & 92 & $\begin{array}{l}5.40 \% \\
(5 / 92)\end{array}$ & $\begin{array}{l}1.10 \% \\
(1 / 92)\end{array}$ & $\begin{array}{l}1.10 \% \\
(1 / 92)\end{array}$ & $\begin{array}{l}0.0 \% \\
(0 / 92)\end{array}$ & $\begin{array}{l}0.0 \% \\
(0 / 92)\end{array}$ & $\begin{array}{l}7.60 \% \\
(7 / 92)\end{array}$ \\
\hline 5 & 35 & $\begin{array}{l}14.30 \% \\
(5 / 35)\end{array}$ & $\begin{array}{l}0.0 \% \\
(0 / 35)\end{array}$ & $\begin{array}{l}2.8 \% \\
(1 / 35)\end{array}$ & $\begin{array}{l}0.0 \% \\
(0 / 35)\end{array}$ & $\begin{array}{l}0.00 \% \\
(0 / 35)\end{array}$ & $\begin{array}{l}0.00 \% \\
(0 / 35)\end{array}$ \\
\hline 6 & 92 & $\begin{array}{l}4.30 \% \\
(4 / 92)\end{array}$ & $\begin{array}{l}3.30 \% \\
(3 / 92)\end{array}$ & $\begin{array}{l}3.30 \% \\
(3 / 92)\end{array}$ & $\begin{array}{l}1.10 \% \\
(1 / 92)\end{array}$ & $\begin{array}{l}1.10 \% \\
(1 / 92)\end{array}$ & $\begin{array}{l}8.70 \% \\
(8 / 92)\end{array}$ \\
\hline Total & 219 & $14(6.4 \%)$ & $4(1.8 \%)$ & $6(2.7 \%)$ & $1(0.5 \%)$ & $1(0.5 \%)$ & $15(6.9 \%)$ \\
\hline
\end{tabular}

a pathogenic protozoa, was found in only one child. The distributions of intestinal parasites in each grade are presented in Table 2. A. lumbricoides infections were found in Grades 4, 5, and 6, while T. trichiura infections were found in Grades 4 and 6. G. lamblia infections were found in Grades 4, 5, and 6. E. histolytica and E. coli infections were found only in Grade 6, while $B$. hominis infections were found in Grades 4 and 6. Thus, these results show that schoolchildren in each grade were infected with intestinal parasites.

Overall, male schoolchildren were more frequently infected with intestinal parasites than female schoolchildren. Of the 41 schoolchildren with a parasite infection, $73.7 \%$ (30/41) were male children, while $27.3 \%$ (11/41) were female. The male:female ratios of intestinal parasite infections indicated that male children were frequently infected by intestinal parasites than female children (Table 3).

Table 3: Intestinal parasitic infections among male and female schoolchildren in Jakarta

\begin{tabular}{llll}
\hline Intestinal parasites & Male & Female & Ratio \\
\hline Helminth & & & $\mathrm{M} / \mathrm{F}$ \\
$\quad$ Ascaris lumbricoides & 8 & 6 & 1.33 \\
$\quad$ Trichuris trichiura & 3 & 1 & 3.0 \\
Protozoa & & & \\
$\quad$ Giardia lamblia & 5 & 0 & 5.0 \\
Entamoeba histolytica & 1 & 1 & - \\
Entamoeba coli & 0 & 2 & - \\
Blastocystis hominis & 13 & 11 & 6.5 \\
Total & 30 & & 2.72 \\
\hline
\end{tabular}

\section{Hb concentrations among schoolchildren}

Table 4 shows the results for the $\mathrm{Hb}$ levels among the schoolchildren. Four schoolchildren

Table 4: Hb concentrations among schoolchildren

\begin{tabular}{llll}
\hline Schoolchildren & $\mathrm{n}$ & $\mathrm{Hb}<12.0 \mathrm{~g} / \mathrm{dL}$ & $\mathrm{Hb}>12.0 \mathrm{~g} / \mathrm{dL}$ \\
\hline $\begin{array}{l}\text { No infection } \\
\text { Infections }\end{array}$ & 178 & 37 & 141 \\
Ascaris lumbricoides & 14 & 4 & 10 \\
Trichuris trichiura & 4 & 0 & 4 \\
Giardia lamblia & 6 & 0 & 6 \\
Entamoeba histolytica & 1 & 0 & 1 \\
Entamoeba coli & 1 & 0 & 1 \\
Blastocystis hominis & 15 & 2 & 13 \\
Total & 219 & $43(19.6 \%)$ & $176(80.4 \%)$ \\
\hline Hb: Hemoglobin & & &
\end{tabular}

infected with $A$. lumbricoides had $\mathrm{Hb}$ concentrations $(<11.5 \mathrm{~g} / \mathrm{dL}$ or $12.0 \mathrm{~g} / \mathrm{dL})$ that indicated anemia, while only one child infected with $B$. hominis was anemic ( $<11.5 \mathrm{~g} / \mathrm{dL} \mathrm{Hb}$ ). Regarding infections with the other parasites, no schoolchildren infected with $T$. trichiura, G. lamblia, E. histolytica, or E. coli were found to be anemic. Among the non-infected schoolchildren, the prevalence of anemia was $16.9 \%$ (37/219), and the overall prevalence of anemia among the schoolchildren was $19.6 \%$. The 41 intestinal parasiteinfected schoolchildren had normal BMI values and no clinical symptoms of intestinal parasites (Table 5). The results of the Chi-square tests indicated that sex was not significantly associated with intestinal parasites among the schoolchildren in Jakarta $(p>0.05)$. However, the species of intestinal parasite was 
Table 5: Hemoglobin, body mass index, and clinical symptoms of the parasite-positive schoolchildren in Jakarta

\begin{tabular}{lllll}
\hline Intestinal parasite & Number positive & $\mathrm{Hb}$ & $\mathrm{BMI}$ & Clinical symptoms \\
\hline Ascaris lumbricoides & 14 & $11.0-14.4$ & $11.6-24.4$ & Asymptomatic \\
Trichuris trichiura & 4 & $12.2-15.6$ & $15.8-24.4$ & Asymptomatic \\
Giardia lamblia & 6 & $13.5-15.5$ & $15.4-30.0$ & Asymptomatic \\
Entamoeba histolytica & 1 & 13.6 & 15.4 & Asymptomatic \\
Entamoeba coli & 1 & 14.2 & 19.2 & Asymptomatic \\
Blastocystis hominis & 15 & $10.5-17.4$ & $13.4-22.2$ & Asymptomatic \\
\hline
\end{tabular}

significantly associated with $\mathrm{Hb}$ concentrations among infected children $(p<0.05)$ (Table 6).

Table 6: Results of Chi-square tests

\begin{tabular}{llllll}
\hline Crosstabs & $\begin{array}{l}\text { Number of } \\
\text { samples }\end{array}$ & \multicolumn{4}{l}{ Chi-square tests } \\
\cline { 3 - 6 } & & $\begin{array}{l}\text { Pearson } \\
\text { Chi-square }\end{array}$ & $\begin{array}{l}\text { Asymp. } \\
\text { sig. }\end{array}$ & $\begin{array}{l}\text { Likelihood } \\
\text { ratio }\end{array}$ & $\begin{array}{l}\text { Asymp. } \\
\text { sig. }\end{array}$ \\
\hline Intestinal parasites $><$ Sex & 41 & 2.942 & 0.23 & 3.31 & 0.191 \\
Type of infection $><\mathrm{Hb}$ & 41 & 33.89 & 0.204 & 48.18 & 0.017 \\
\hline
\end{tabular}

Anemia; $\mathrm{Hb}$ concentration $<11.5 \mathrm{~g} / \mathrm{dL}$ for $6-11$ years old and $12.0 \mathrm{~g} / \mathrm{dL}$ for $12-15$ years old. Nonanemia; $\mathrm{Hb}$ concentration $>12.0 \mathrm{~g} / \mathrm{dL}$ [17].

\section{Discussion}

This study was conducted in a primary school in an urban area in Jakarta, Indonesia. Since 2019, the primary school has implemented a deworming program in accordance with the WHO recommendations [10]. After 1 year of the program, this study examined IPIs, including STH and intestinal protozoan infections, among the schoolchildren. $A$. lumbricoides and T. trichiura infections were found among schoolchildren who did not exhibit any clinical symptoms. Our findings are line with the previous studies that reported that A. lumbricoides and $T$. trichiura were the most common STH infections among schoolchildren [18], [19], [20]. The prevalences of $A$. lumbricoides (6.4\%) and T. trichiura $(1.8 \%)$ were lower among the schoolchildren in Jakarta than in India, where the prevalences of $A$. lumbricoides and $T$. trichiura were found to be $8.1 \%$ and $3.7 \%$, respectively [21].

Deworming programs do have an impact on STH infections. Many factors are associated with A. lumbricoides and T. trichiura infections [22]. Dahal et al. [20] reported that the age and type of toilet used by schoolchildren were significantly associated with STH infections. Other risk factors that contribute to STH infections are hand washing [19], never undergoing deworming, and lack of a facility for defecation [21]. The present study found that $97.3 \%$ of the schoolchildren used a latrine in their homes. In addition, a school deworming program is being implemented in Jakarta. Thus, the deworming program and the presence of latrines in the home resulted in the low prevalences of A. lumbricoides and T. trichiura among the schoolchildren in Jakarta. A deworming program that uses albendazole (single dose $400 \mathrm{mg}$ ) administered once a year can decrease infections with $A$. lumbricoides, $T$. trichiura, and other parasites, but the STHs still persist because albendazole alone is not sufficient to improve the health conditions of vulnerable populations [12]. Another study showed that reinfections with STH occurred among children after treatment with anthelmintic drugs [23].

The deworming program has impacted protozoan infections among schoolchildren in Jakarta. In this study, protozoan infections were examined after 1 year of implementing the deworming program, and the results indicated that the protozoan infections consisted of G. intestinalis, E. histolytica, E. coli, and B. hominis. In Tamil Nadu, India, E. histolytica (23.2\%) and G. lamblia $(5.2 \%)$ were the most common protozoan infections among female schoolchildren [24]. In Nepal, the protozoan infections found among schoolchildren were $E$. histolytica and G. lamblia [25]. The prevalence of G. lamblia is higher in urban areas than in rural areas. In Tripoli, Lebanon, the prevalence of Blastocystis spp. (63\%) was higher than those of Dientamoeba fragilis $(60.6 \%)$, G. duodenalis (28.5\%), and Cryptosporidium spp. (10.4\%) [26]. Similarly, the present study found that $B$. hominis $(6.8 \%)$ and $G$. lamblia $(2.7 \%)$ were the most common protozoan infections among schoolchildren in Jakarta.

Protozoan infections are transmitted through the fecal-oral route. The ingestion of contaminated water or food and person-to-person transmission are the most frequent routes [27]. Several studies have determined that the risk factors of protozoan infections among schoolchildren include contact with family members who are suffering from gastrointestinal disorders [26], suboptimal water quality [28], drinking untreated water [29], drinking water from tanks, and washing hands with only water [30], [31]. In the present study, it was found that schoolchildren who were infected with one or more intestinal protozoa used only the untreated tap water provided in their school for washing their mouths and hands. Moreover, they used untreated water sources from wells, pumps, and piped sources.

A previous study showed that male schoolchildren had higher rates of IPIs than female children. Hailegebriel [31] reported that the prevalences of IPIs were $33.5 \%$ and $32 \%$ among male and female students, respectively, in Bahir Dar, Ethiopia, while in Jawi town, Northwest Ethiopia, the prevalences of intestinal parasites among male and female students were $51.85 \%$ and $45.3 \%$, respectively [32]. Similarly, the present study showed that $73.7 \%(30 / 41)$ of the students infected with intestinal parasites were male and that $27.3 \%$ were female. Possible explanations for this difference are that male students more frequently play in contaminated soil and water than female students and that male students have a lower level of awareness of the transmission of intestinal parasites than female students [32].

Overall, the prevalence of $\mathrm{Hb}$ concentrations $<12.0 \mathrm{~g} / \mathrm{dL}$ (anemia) among the schoolchildren in Jakarta was $19.6 \%$. In Ethiopia, the prevalence of anemia 
among schoolchildren was reported to be $23 \%$ [33], in Northwest Ethiopia, 33.9\% [34], and in Eastern Nepal, $31.6-45.5 \%$ [35]. Many factors are associated with anemia in children. For example, Birhanu et al. [34] reported that a mother who is illiterate $(A O R=7.595 \%$ $\mathrm{Cl}=2.6-16.3)$, low income $(\mathrm{AOR}=4.895 \% \mathrm{Cl}=1.3$ 10.9), stunted growth $(\mathrm{AOR}=7.195 \% \mathrm{Cl}=2.9-11.9)$, being underweight $(\mathrm{AOR}=5.295 \% \mathrm{Cl}=2.1-13.3)$, intestinal parasite infections $(\mathrm{AOR}=5.295 \% \mathrm{Cl}=2.1-$ 12.6), and malaria infection (AOR $=8.295 \% \mathrm{Cl}=1.8$ 14.5) was significantly associated with anemia among schoolchildren in Northwest Ethiopia. In the present study, multivariate logistic regression was no performed, but we expect that the IPIs alone are not responsible for the low $\mathrm{Hb}$ concentrations among the schoolchildren and that the low education level of the mothers and low family income may contribute the low $\mathrm{Hb}$ levels (anemia), in accordance with the previous studies [34].

\section{Conclusion}

The most frequently found infections in schoolchildren in Jakarta who have participated in the deworming program were $B$. hominis and G. Iamblia, whereas $A$. lumbricoides was the most frequently found STH infection. The infections with helminths and protozoa among the schoolchildren were attributed to their washing their mouths and hands with only untreated water from taps, wells, pumps, and piped sources. The low prevalences of $A$. lumbricoides and $T$. trichiura were likely due to the deworming program, which uses a single dose of albendazole. IPIs were associated with the prevalence of low $\mathrm{Hb}$ concentrations (anemia) among the schoolchildren.

\section{Acknowledgments}

The University of Indonesia funded the study, DRPMUI Hibah Pengabdian Masyarakat Tahun 2019. We thank all of the participants, the chairman, and the teachers at the primary school, SDN Kalibaru 09 PG, North Jakarta, and the medical doctors, nurses, and health workers at the Primary Health Care Centre, Kalibaru, North Jakarta, for participating in the study.

\section{References}

1. Bethony J, Brooker S, Alabonica M, Geiger SM, Laukas A Diemert D, et al. Soil-transmitted helminth infections: Ascariasis, trichuriasis, and hookworm. Lancet. 2006;367(9521):1521-32. https://doi.org/10.1016/s0140-6736(06)68653-4

PMid:16679166

2. Stanley SL Jr., Reed SL. Microbes and microbial toxins: Paradigms for microbial-mucosal interactions. VI. Entamoeba histolytica: Parasite-host interactions. Am J Physiol Gastrointest Liver Physiol. 2001;280(6):G1049-54. https://doi.org/10.1152/ ajpgi.2001.280.6.g1049

PMid:11352795

3. Ayele BH, Geleto A, Ayana DA, Redi M. Prevalence of fecooral transmitted protozoan infections and associated factors among university students in Ethiopia: A cross-sectional study. BMC Infect Dis. 2019;19(1):499. https://doi.org/10.1186/ s12879-019-4095-z

PMid:31174474

4. Jourdan PM, Lamberton PH, Fenwick A, Addiss DG. Soiltransmitted helminth infections. Lancet. 2018;391(10117):25265. https://doi.org/10.1016/s0140-6736(17)31930-x PMid:28882382

5. Centers for Disease Control and Prevention (CDC). Trichuriasis (Alos Known as Whipworm Infections); 2013. Available from: https://www.cdc.gov/parasites/whipworm. [Last Accessed 2020 Jun 22].

6. Gardner TB, Hill DR. Treatment of giardiasis. Clin Microbiol Rev. 2001;14(1):114-28

PMid:11148005

7. Wawarzyniak I, Poirier P, Viscogliosi E. Dionigia M, Texier C,Delbac F. Blastocystis, an unrecognized parasite: An overview of pathogenesis and diagnosis. Ther Adv Infect Dis. 2013;1(5):167-78.

PMid:25165551

8. El-Dib NA. Entamoeba histolytica: An overview. Curr Trop Med Rep. 2017;4:11-20. https://doi.org/10.1007/s40475-017-0100-z

9. Ashtiani MT, Monajemzadeh M, Saghi B, Shams S, Mortazavi SH, Khaki S, et al. Prevalence of intestinal parasites among children referred to children's medical center during 18 years (19912008), Tehran, Iran. Ann Trop Med Parasitol. 2011;105(7):50713. https://doi.org/10.1179/1364859411y.0000000040 PMid:22185945

10. World Health Organization. Deworming to Combat the Health and Nutritional Impact of Soil-Transmitted Helminthes; 2012. Available from: https://www.who.int/elena/titles/bbc/deworming/ en. [Last Accessed 2020 Jun 22].

11. Schmidlin T, Hurlimann E, Silue KD, Yapi RB, Houngbedji C, Kouadio BA, et al. Effects of hygiene and defecation behavior on helminths and intestinal protozoa infections in Taabo, Cote d'Ivoire. PLoS One. 2013;8(6):e65722. https://doi.org/10.1371/ journal.pone.0065722

PMid:23840358

12. Quihui-Cota L, Morales-Figueroa GG. Persistence of intestinal parasitic infections during the national de-worming campaign in schoolchildren of northwestern Mexico: A cross-sectional study. Ann Gastroenterol. 2012;25(1):57-60.

PMid:24714136

13. Koukounari A, Estambale BB, Njagi JK, Cundill B, Ajanga A Crudder $C$, et al. Relationships between anaemia and parasitic infections in Kenyan schoolchildren: a Bayesian hierarchical modelling approach. Int J Parasitol. 2008;38(14):1663-71.

PMid:18621051

14. World Health Organization. Bench Aids for the Diagnosis of Intestinal Parasites. $2^{\text {nd }}$ ed. Geneva: World Health Organization; 2019. p. 1-32. Available from: https://www.who. int/intestinal_worms/resources/9789241515344/en. [Last Accessed 2020 Jul 01]. 
15. User Manual, Easy Touch GCHb. Available from: https:// www.5.imimg.com/data5/dd/vs/cj/seller-28906720/easy-touchmeter.pdf. [Last Accessed 2020 Jun 26].

16. Ugoni A, Walker BF. The chi square test: An introduction. COMSIG Rev. 1995;4(3):61-4. PMid:17989754

17. Sullivan KM, Mei Z, Grummer-Strawn L, Parvanta I. Haemoglobin adjustments to define anaemia. Trop Med Int Health. 2008;13(10):1267-71. https://doi. org/10.1111/j.1365-3156.2008.02143.x PMid:18721184

18. Silver ZA, Kaliappan SP, Samuel P, Venugopal S, Kang G, Sarkar R, et al. Geographical distribution of soil transmitted helminths and the effects of community type in South Asia and South East Asia-a systematic review. PLoS Negl Trop Dis. 2018;12(1):e0006153. https://doi.org/10.1371/journal. pntd.0006153 PMid:29346440

19. Gelaw A, Anagaw B, Nigussie B, Silesh B, Yirga A, Alem M et al. Prevalence of intestinal parasitic infections and risk factors among schoolchildren at the University of Gondar Community School, Northwest Ethiopia: A cross-sectional study. BMC Public Health. 2013;13:304. https://doi.org/10.1186/1471-2458-13-304 PMid:23560704

20. Dahal AS, Francis EO, Francis JE, Wamtas FI. Soiltransmitted Helminths and Associated Risk Factors among Elementary School Pupils in Dadin Kowa, Jos. Niger Med J. 2019;60(4):181-5. https://doi.org/10.4103/nmj.nmj_62_19 PMid:31831936

21. Ranjan S, Passi SJ, Singh SN. Prevalence and risk factors associated with the presence of soil-transmitted helminths in children studying in municipal corporation of Delhi schools of Delhi, India. J Parasit Dis. 2015;39:377-84. https://doi. org/10.1007/s12639-013-0378-2

PMid:26345038

22. Yang $D$, Yang $Y$, Wang $Y$, Yang $Y$, Dong $S$, Chen $Y$, et al. Prevalence and risk factors of ascaris lumbricoides, trichuris trichiura and cryptosporidium infections in elementary schoo children in Southwestern China: A school-based cross-sectional study. Int J Environ Res Public Health. 2018;15(9):1809. https:// doi.org/10.3390/ijerph15091809

PMid:30135364

23. Speich B, Moser W, Ali SM, Ame SM, Albonico M, Hattndorf J, et al. Efficacy and reinfection with soil-transmitted helminthes 18 weeks post-treatment with albendazole-ivermectin, albendazole-mebendazole, albendazole-oxantel pamoate and mebendazole. Parasit Vectors. 2016;9:123-33. https://doi. org/10.1186/s13071-016-1406-8

\section{PMid:26935065}

24. Gopalakhrisnan S, Eashwar VM, Muthulaksmi M, Geetha A. Intestinal parasitic infestations and anemia among urban female school children in Kancheepuram district, Tamil Nadu. J Family Med Prim Care. 2018;7(6):1396-400. https://doi.org/10.4103/ jfmpc.jfmpc_89_18 PMid:30613531

25. Tandukar S, Ansari S, Adhikari N, Shrestha A, Gautam J, Sharma B, et al. Intestinal parasitosis in school children of Lalitpur district of Nepal. BMC Res Notes. 2013;6:449. https:// doi.org/10.1186/1756-0500-6-449

\section{PMid:24207086}

26. Osman M, El Safadi D, Cian A, Benamrouz S, Nourrisson C Poirier $\mathrm{P}$, et al. Prevalence and risk factors for intestinal protozoan infections with cryptosporidium, Giardia, Blastocystis and Dientamoeba among schoolchildren in Tripoli, Lebanon. PLoS Negl Trop Dis. 2016;10(3):e0004496. https://doi. org/10.1371/journal.pntd.0004496 PMid:26974335

27. Leung AK, Leung AA, Wong AH, Sergi CM, Kam JK. Giardiasis: An overview. Recent Pat Inflamm Allergy Drug Discov. 2019;13(2):134-43. https://doi.org/10.2174/18722 $13 \times 13666190618124901$

\section{PMid:31210116}

28. Hernández PC, Morales L, Chaparro-Olaya J, Sarmiento D, Jaramillo JF, Ordoñez GA, et al. Intestinal parasitic infections and associated factors in children of three rural schools in Colombia. A cross-sectional study. PLoS One. 2019;14(7):e0218681. https://doi.org/10.1371/journal.pone.0218681

PMid:31291262

29. Gyang VP, Chuang TW, Liao CW, Lee YL, Akinwale OP, Orok A et al. Intestinal parasitic infections: Current status and associated risk factors among school aged children in an archetypa African urban Slum in Nigeria. J Microbiol Immunol Infect. 2017;52(1):106-13. https://doi.org/10.1016/j.jmii.2016.09.005 PMid:28711437

30. Bakarman MA, Hegazi MA, Butt NS. Prevalence, characteristics, risk factors, and impact of intestinal parasitic infections on school children in Jeddah, Western Saudi Arabia. J Epidemiol Glob Health. 2019;9(1):81-7. https://doi.org/10.2991/ jegh.k.190219.001 PMid:30932395

31. Hailegebriel T. Prevalence of intestinal parasitic infections and associated risk factors among students at Dona Berber primary school, Bahir Dar, Ethiopia. BMC Infect Dis. 2017;17(1):362. https://doi.org/10.1186/s12879-017-2466-x PMid:28535750

32. Sitotaw B, Mekuriaw H, Damtie D. Prevalence of intestinal parasitic infections and associated risk factors among Jawi primary school children, Jawi town, North-West Ethiopia. BMC Infect Dis. 2019;19(1):341. https://doi.org/10.1186/ s12879-019-3971-x PMid:31023271

33. Tezera R, Sahile Z, Yilma D, Misganaw E, Mulu E. Prevalence of anemia among school-age children in Ethiopia: A systematic review and meta-analysis. Syst Rev. 2018;7(1):80. https://doi. org/10.1186/s13643-018-0741-6 PMid:29793528

34. Birhanu M, Gedefaw L, Asres Y. Anemia among school-age children: Magnitude, severity and associated factors in Pawe town, Benishangul-Gumuz region, Northwest Ethiopia. Ethiop J Health Sci. 2018;28(3):259-66. https://doi.org/10.4314/ejhs. v28i3.3

\section{PMid:29983525}

35. Khatiwada S, Gelal B, Gautam S, Tamang MK, Shakya PR, Lamsal M, et al. Anemia among school children in eastern Nepal. J Trop Pediatr. 2015;61(3):231-3. https://doi.org/10.1093/tropej/ fmv016

PMid:25828831 